\title{
Diseurso por ocasião da formatura do Eurso de Bacharelado em Telogia da FACASC
}

A FACASC - Faculdade Católica de Santa Catarina - alegra-se sobremaneira pela formatura de mais uma turma do seu Bacharelado em Teologia. É a segunda de sua curta existência como Instituição de Ensino Superior, reconhecida e credenciada pelo Ministério da Educação. Dentro de alguns dias, 30 de dezembro, para ser preciso, serão comemorados cinco anos dessa criança educadora que, como toda criança, embala o sonho de crescer, ser grande e feliz. Portanto, é com orgulho e consciência de dever cumprido que encerra, nesta sessão solene de colação de grau, a sua missão docente neste ano de 2016.

Senhoras e senhores, presentes a este ato: ilustres membros componentes desta mesa, outros colegas professores dispersos nesta assembleia, queridos formandos, seus venerandos pais, mães e demais parentes, faço chegar a todos, indistintamente, a expressão mais afetuosa e muito cordial da minha saudação. Boa noite.

TEOLOGIA. Desde que se cunhou este termo - as primeiras notícias tradicionalmente remontam ao século IV da era pré-cristã - e se começou a sua reflexão, muitas pessoas a tem transformado no objeto preferido do seu interesse. De Platão a nossos dias, ininterruptamente, a Teologia tem constituído pólo de atração e mesmo fascínio de muitos estudiosos. De lá para cá, a humanidade tem passado por inúmeras transformações e a Teologia tem se mantido de pé. Um corte vertical, entretanto, marcou decisivamente a sua trajetória, o advento do cristianismo. Se os antigos gregos, e possivelmente outros povos e culturas, tinham motivo para especular sobre deuses, sobre a origem do universo e a existência do ser humano, muito mais o tinham os cristãos, que herdaram do povo hebreu a crença no Deus único de Abraão, Isaac e Jacó, da criação como obra de suas mãos e do homem e mulher como imagem e semelhança dele, com o acréscimo, fato inusitado, da humanização do seu Filho Unigênito (imagem e arquétipo da imagem) e a consequente divinização da humanidade, fato extraordinário. De fato, a partir do momento em que o Verbo se fez carne e habitou entre nós (Jo 1,14), a 
Teologia passa a ter o seu perfil bem delineado: refletir as maravilhas desse mistério encarnado e torná-las acessíveis a todos, independente de classe, raça, gênero, condição social etc.

FAZER TEOLOGIA tem sido um ideal perseguido por muitos, mas realizado por menos. Na atualidade, o panorama oferecido pela sociedade acadêmica é recheado de possibilidades, na área das ditas ciências humanas, e sabemos que a Teologia é opção de uma exígua cifra dentre os inúmeros estudantes. Frente a essa realidade, tanto mais pertinente torna-se a pergunta quanto sua resposta. Pergunta: Por que e para que alguns ainda querem fazer Teologia? A resposta encontra-se na definição desse objeto de estudo, aqui trazida de forma simplificada e acessível: a ciência que estuda Deus, as coisas divinas, as coisas humanas na ótica de Deus. Portanto, estudar teologia é, antes de tudo, um ato de fé que busca aprofundamento através do intelecto (fides quaerens intellectum).

Foi essa façanha que este grupo de quinze membros, rapazes e senhores, realizou ao longo destes últimos quatro anos, coroada com este momento solene. Nove são seminaristas maiores (mas este número pode alterar-se a qualquer momento!). Esses irão abraçar a carreira eclesiástica, através do ministério ordenado diaconal e, em seguida, presbiteral, cinco são diocesanos e quatro religiosos.

Os outros seis são leigos e deverão engrossar as fileiras, sempre maiores, dos que, desvinculados da vida consagrada, agregam ao seu cursus honorum o itinerário dos estudos teológicos. Ainda são minoria, mas não devem ser vistos como exceção. Neste ano, a CNBB publicou um novo documento sobre os leigos, e isso também vem a somar como indicativo de um reconhecido protagonismo.

[Um parêntese: Nenhuma mulher figura entre estes formandos! Mais do que um detalhe, isso deve ser um lamento, porque no mundo leigo e na vida consagrada, na missão evangelizadora, a mulher é maioria, atuando em várias frentes de pastoral, fermento e fermentadora do Reino de Deus].

Voltando aos formandos, a maioria está concluindo o seu segundo curso superior, alguns o seu primeiro e menos o seu terceiro. Notas comuns: Todos submeteram-se ao longo processo de aprendizado, foram bem sucedidos nos exames, tiveram frequência suficiente. Ensaiando uma linguagem mistagógica, emprestada a Paulo (cf. 1Cor 10,1-4), todos estiveram debaixo da nuvem, atravessaram o mar (não se afogaram), 
foram iniciados e batizados, comeram e beberam da mesma comida e bebida espiritual, extraída do depósito de fé da Igreja e, sobretudo, da rocha que é o próprio Cristo. Perfizeram o currículo do Bacharelado do curso de Teologia, confessional, católica; todos estão formados, todos são teólogos.

Não pode passar sob silêncio a situação nacional onde um enorme contingente de estudantes ainda não consegue sequer concluir o ensino médio. Portanto, o canudo de um curso superior comporta uma grande responsabilidade social. Logo, o apelativo maior, a partir de agora, será a aplicação dos conhecimentos adquiridos. Existem várias maneiras de aplicar a Teologia; a pastoral é uma delas. E aqui é preciso se estar muito atento para não ceder a tentações que seguramente baterão em cada porta. É fundamental não confundir evangelização com autossatisfação, missão com deleite, pastoral com fonte de realização individual. Exige-se consciência, senso de responsabilidade e honestidade intelectual. É preciso olhar o país e o mundo à nossa volta: a crise econômica é assustadora, o caos político avassalador, as famílias vivem sob pressão de diversas ordens, destacam-se os temas planetários da migração e da devastação ambiental, dentre outros.

Como contemplar essa realidade da ótica teológica e qual discurso lançar sobre essa "epistemologia"? Se tudo isso é pouco, que se pense nos sofredores. Falta inspiração? Que se lembre das tantas famílias recentemente enlutadas em nosso Estado (acidente aéreo do final de novembro), das vítimas da inclemência climática, enfim. Como alimentar uma mística capaz de considerar tudo isso e não sepultar-se na tristeza e desencanto? Como sentir e apresentar a alegria do Evangelho em cenários de fracasso? Perguntem-se, caros formandos, como a Teologia pode ajudá-los a enfrentar esses abismos do tempo presente. Existem muitas questões em aberto à espera de respostas convincentes e eficazes. É hora de buscá-las. Isso haverá de se dar pela reflexão e prática, pela multiplicação de conhecimento e testemunho.

É preciso fugir às pastorais descompromissadas, às reflexões obsoletas, às práticas postiças, às liturgias estranhas. Não deve haver divórcio entre a Teologia que se estudou e a que se vai pôr em prática nas futuras atividades. Ninguém tem o direito ao descompromisso, à despreocupação e à inconsequência. Nesse cenário, a caridade deve brilhar como a pedra mais preciosa; ela é a seiva que alimentará cada ação, cada obra, que 
sustentará cada projeto vocacional. Só ela permanecerá, quando tudo tiver passado (cf. 1Cor 13,8).

[Acho que estou ficando velho, porque me canso com e por muito pouco! E surpreendo-me aconselhando e ajuizando jovens].

Interrompo aqui este receituário que poderia se alongar, até porque as esquizofrenias são tão variadas quanto assustadoras. Entretanto, dou meu testemunho pessoal, declarando que valeram a pena esses quatro anos que os tive como alunos, valeu a pena, este ano - primeiro da série - que, com a colaboração e dedicação de muitos, alguns de mais longe e outros mais de perto, dirigi a FACASC e a conduzi até este momento, ponto culminante do nosso calendário acadêmico. Por tudo, uno a ação de graças de vocês, formados, à minha própria, e externo, ao corpo docente, discente e técnico administrativo sentimentos de profunda gratidão. A todos os presentes faço chegar manifestos de abençoado e santo Natal, com as melhores alvíssaras para o novo ano que se aproxima.

A pena tanto mais vale, quando nobre é o objetivo a ser alcançado. Valeu a pena o garimpo destas letras e palavras, concatenadas ao longo de algumas horas desta semana, para alinhar este breve discurso e solenizar este momento. Tudo vale a pena se a alma não é pequena. A frase de Fernando Pessoa é conhecida, densa e sugere um gran finale para este discurso, mas atrevo-me a ir além e abrir os baús da memória e, como faço tantas vezes, chegar até a infância.

Na cidade de Imbituba, onde nasci, me criei e aprendi as primeiras letras, havia uma mulher que recitava poemas pelas ruas; era uma sorte de andarilha. Chamavam-na louca, nós todos a chamávamos louca; ela chamava-se Antolina.

Certo dia, ao voltarmos da escola, eu estava no primeiro ano do grupo, nos reunimos vários escolares à sua volta para ouvir alguma das suas inumeráveis pérolas que ela, em meio a trejeitos e altercações, soltava a cópias. Pedimos um versinho: Ela rodopiou - qual sunamita! - e num relance sequestrou uma de nossas canetas, olhou fixo para um colega, e poetou: Apenas peguei na pena, apenas para mostrar, quando escrevi seu nome, a pena me fez chorar. $\mathrm{O}$ riso foi geral; e a banalidade do momento e a imaturidade própria daquela idade não permitiam, nem a mim, nem aos colegas, colher o sentido profundo daquela ciência. Foi preciso tempo, anos, décadas, para que entendesse que era uma sabedoria diferente, alheia às cátedras e bancos escolares. Colhida na 
informalidade de uma esquina, era maturada por experiências de vida, às vezes das mais duras.

Um segredo: comecei este discurso sem gosto, sem ânimo e sem sabor, apenas letras enfileiradas e palavras encadeadas, mais um protocolo a ser cumprido na minha lista inumerável, com a agravante dessa 'armadura' barroca, quase rococó, que envolvem algumas locuções das ocasiões como esta.

A memória dessa louca - hoje a chamo sábia - acendeu o meu entusiasmo de continuar na pena e da pena extrair-lhes alguma lição de vida; fez-me sentir com um dever a cumprir. Lamentei, com pena, ter esquecido toda a sua riqueza poética à exceção desta supra mencionada. Resgatá-la do esquecimento, do seu eterno repouso e evocá-la, citá-la a comparecer diante do tribunal da consciência e publicá-la desta cátedra traz uma mensagem implícita. Antolina, Requiescat in Pace (RIP), descansa em paz!

Muitos aqui frequentaram, frequentamos muitas cátedras. Na teologia, da cátedra aos bancos escolares, vocês, estudantes de ontem, formando-se hoje, conheceram muitos mestres, sábios, até renomados teólogos das mais diversas áreas, real ou bibliograficamente. Entretanto, se numa esquina, da rua, da pastoral, da vida, encontrarem uma louca, ou uma sábia, que lhes lance alguma pérola teológica, nova, fresca, única, não hesitem: agarrem-na. Forço essa analogia da preciosa experiência poética e reforço os conselhos já dados. Em circunstâncias conhecidas: "Jesus pronunciou estas palavras: Eu te louvo, ó Pai, Senhor do céu e da terra, porque escondeste estas coisas aos sábios e entendidos e as revelaste aos pequeninos" (Mt 11,25).

$\mathrm{Na}$ frente da Pontifícia Universidade Gregoriana, em Roma, onde muitos de nós professores estudamos, havia anos atrás, uma senhora que passava várias horas do dia gritando em italiano: studiate, studiate, più pazzi diventate! (estudem, quanto mais vocês estudam, mais loucos vocês ficam!). Esta é uma outra história que merece ser contada na ocasião de uma outra formatura...

Florianópolis, 10 de dezembro de 2016

Pe. Edinei da Rosa Cândido

Diretor Geral da FACASC 